\title{
Does COVID-19 Uses ACE-2-Receptors of the Epidermis As Entry into the Body?
}

ISSN: 2576-9200

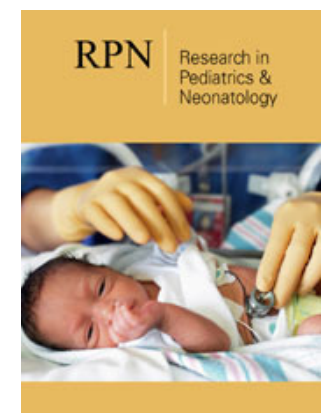

*Corresponding author: Bittmann S, Head of the Department of Pediatrics, Ped Mind Institute, Gronau, Germany

Submission: 非 April 11, 2020

Published: 制April 20, 2020

Volume 4 - Issue 3

How to cite this article: Bittmann $\mathrm{S}$, Weissenstein A, Villalon G, et al. Does COVID-19 Uses ACE-2-Receptors of the Epidermis As Entry into the Body?. Res Pediatr Neonatol. 4(3). RPN. 000590.2020. DOI: $10.31031 / R P N .2020 .04 .000590$

Copyright $\odot$ Bittmann S. This article is distributed under the terms of the Creative Commons Attribution 4.0 International License, which permits unrestricted use and redistribution provided that the original author and source are credited.
Bittmann S*, Weissenstein A, Villalon G, Moschüring-Alieva E, Bittmann L and Luchter $\mathrm{E}$

Department of Pediatrics, Germany

\section{Introduction}

Since the outbreak in China in December 2019 researchers searching for adequate therapy to control viral spreading and to inhibit COVID-19 effectively. To date, no effective drug to treat this severe viral infection was found. Publications about angiotensin II receptor blocker reveal a new effective method to think about in treating COVID-19 [1-5]. Moreover, different therapy options were started to stop the devastating potential of COVID-19 worldwide. Antibody-rich donated plasma from survivors, different inhibitors are part of analysis to stop the entry of the virus into the cell and disturb the connection between SARS-CoV-2 and angiotensin-2 receptor binding. Angiotensin II and the receptor play an important role in cell entry of COVID-19. For cell entry COVID-19 needs the presence of a serine protease TMPRSS2 and cathepsin L [6-9].

ACE-2 receptors are found in different organs and can induce individual organ failure in COVID-19 patients, like it was described a few days ago in brain tissue by Jiao et al. \& Poyiadji et al. [3,11]. In neurotrope tissues, COVID-19 seems to trigger viral necrotic encephalitis. To date, COVID-19 seems to get part of the human body by docking to ACE- 2 receptors in the oral cavity and the tongue [12]. Both studies of Stecklings et al. examined the expression of Angiotensin receptors in the human skin, the possible synthesis of Angiotensin II (Ang II) at this point and looked for the first insight into the physiological functions. AT1 and AT2 receptors were found in the epidermis and in the dermal vascular walls $[10,13]$. The same expression pattern was found for Angiotensinogen, renin and Angiotensin Converting Enzyme (ACE). All components could be proved, in addition, at mRNA level in cultured primary ceratinozyts, melanozyts, with the exception of the AT2 receptors in melanocytes $[10,13]$.

\section{Conclusion}

In conclusion, studies have shown that ACE2 and ACE-2 receptors were found in the skin, especially in the epidermis and the dermal vascular walls, suggesting that COVID-19 could find an entry into the human body by epidermal contact, then docking to ACE 2 in the skin $[10,13]$. If this hypothesis is correct, all medical staff must work with skin protective gear and all humans should take care that closer skin contact could transmit COVID-19. Further research in this field is necessary.

\section{References}

1. Bittmann S (2020) Covid-19-the role of children and search for effective treatment options with promising view to Angiotensin II inhibitors. American Journal of Biomedical Science and Research 8(4): 207.

2. Bittmann S (2020) COVID-19 in adults and children: The clock is ticking. J Regen Biol Med 2(2):1-2.

3. F Jiao, Bittmann S (2020) A new classification of clinical findings and treatment options of SARSCoV-2 infection in children from China. Advances of Pediatric Research 7(1): 37.

4. Bittmann S, Luchter E, Villalon G, Moschüring-Alieva E, Weissenstein A (2020) Clinical Landmarks of COVID-19 in newborn, children and teenagers. Journal of Pediatric Health and Nutrition 1(3): 1-2.

5. Bittmann S (2020) COVID-19: What we know. Journal of Pediatric Health and Nutrition 1(1): 27.

6. Hoffmann M, Weber KH, Schroeder S, Muller MA, Drosten C, et al. (2020) SARS-CoV-2 cell entry depends on ACE2 and TMPRSS2 and is blocked by clinically proven protease inhibitor. Cell 181: 1-19. 
7. Coote K, Watson AHC, Sugar R, Young A, BeevorMA, et al. (2009) Camostat attenuates airway epithelial sodium channel function in vivo through the inhibition of a channel-activating protease J Pharmacol Exp Ther 329(2): 764-774.

8. Gibo J, Ito T, Kawabe K, Hisano T, Inoue M, et al. (2005) Camostatmesilate attenuates pancreatic fibrosis via inhibition of monocytes and pancreatic stellate cells activity. Lab Invest 85(1): 75-89.

9. Simmons G, Rosalia DN, Rennekamp AJ, Reves JD, Diamond SL, et al. (2005) Inhibitors of cathepsinLprevent severe acute respiratory syndrome coronavirus entry. Proc Natl Acad Sci U S A 102(33): 1187611881.
10. Steckelings UM, Henz BM, Wiehstutz S, Unger T, Artuc M (2005) Differential Expression of Angiotensin Receptors in Human Cutaneous Wound Healing. Br J Dermatol 153(5): 887-893.

11. Poyiadji N, Schien G, Noujaim D, Stone M, Patel S, et al. (2020) Covid-19associated acute hemorrhagic necrotizing encephalopathy: CT and MRI features. Images in Radiology.

12. Zhao Y, Zhao Z, Wang Y, Zhou Y, Yu Ma, et al. (2020) Single-cell RNA expression profiling of ACE2, the putative receptor of Wuhan 2019-nCov.

13. Steckelings UM, Wollschläger T, Peters J, Henz BM, Hermes B, et al. (2004) Human skin: Source of and target organ for angiotensin II. ExpDermatol 13(3): 148-154. 